\title{
Społeczne zakotwiczenie w klasowo-etnicznych formach tożsamości a integracja polskich i ukraińskich migrantów
}

Artykuł prezentuje wyniki badania, którym objęte zostały opublikowane w mediach społecznościowych wypowiedzi migrantów z Polski w Wielkiej Brytanii i z Ukrainy w Polsce. Do analizy wykorzystano koncepcję społecznego zakotwiczania, która odnosi się do procesu poszukiwania życiowych punktów oparcia - kotwic, pozwalających jednostkom na osiągnięcie psychospołecznej stabilizacji i efektywne funkcjonowanie w nowych warunkach. Przeprowadzone badanie wskazało nie tylko na rolę kotwic obiektywnych, takich jak praca zarobkowa, zasoby materialne i warunki instytucjonalne kraju przyjmującego, lecz także na znaczącą rolę kotwic osadzonych w relacjach społecznych. Zarówno migranci z Polski, jak i z Ukrainy zakotwiczają się mentalnie w wyobrażonych wspólnotach, konstruując klasowo-etniczne formy tożsamości, które stanowią ich punkty odniesienia w nowych warunkach społeczno-kulturowych. Polscy migranci budują wspólnoty wyobrażone, wykorzystując jako grupy odniesienia białych Brytyjczyków oraz przedstawicieli mniejszości etnicznych i grup migranckich o pozaeuropejskich korzeniach. Jednocześnie w ich narracjach podkreślane są różnice klasowe i edukacyjne w obrębie społeczności polskich migrantów. Migranci z Ukrainy konstruują tożsamość w odniesieniu do wartości europejskich oraz przedstawicieli społeczeństwa przyjmującego $\mathrm{w}$ warunkach znoszenia wszelkich różnic związanych z ich pozycją społeczno-ekonomiczną. W analizowanych narracjach w obu badanych grupach preferowane są postawy prointegracyjne.

Słowa kluczowe: społeczne zakotwiczenie, migranci, integracja, ukraińscy migranci, polscy migranci, tożsamość, media społecznościowe

\footnotetext{
${ }^{1}$ Kontakt: brzozowskaa@is.uw.edu.pl
} 


\section{Social Anchoring in Class-Ethnic Identities and Integration of Polish and Ukrainian Migrants}

The article presents the analysis of posts published in social media by Polish migrants settled in the United Kingdom and Ukrainian migrants in Poland. The paper uses the concept of social anchoring defined as the process of searching for points of reference (anchors) which allow individuals to acquire socio-psychological stability and security and function effectively in a new life environment. The research showed the role of objective anchors such as employment, economic resources and institutional environment of the destination country as well as the crucial role of anchors embedded in social relations. Migrants from both analysed groups anchored themselves in strategically-imagined communities while constructing their ethnic and class identities that became their points of references in the new socio-cultural environment. In the narratives of Polish migrants in the UK the main reference groups are white, British citizens on one side and members of non-European minorities on the other. At the same time Polish migrants emphasize class and educational differences among the Polish community in the UK. In the case of the Ukrainian migrants in Poland the main reference group consists of members of the Polish, homogenous society. They also construct their identities with reference to European values. The research showed that in narratives of both analysed groups a pro-integration attitude is preferred.

Keywords: Social Anchoring, Migrants, Integration, Ukrainian Migrants, Polish Migrants, Identity, Social Media

\section{Wprowadzenie}

Jedną z elementarnych ludzkich potrzeb jest poczucie stabilności i bezpieczeństwa. Tymczasem jednostki w obliczu wzrostu złożoności i nieprzewidywalności współczesnych społeczeństw doświadczają w coraz większym stopniu deficytu bezpieczeństwa i osobistej spójności oraz szeroko rozumianej niestabilności (Gergen 2009). W obliczu zmian nasilają się egzystencjalne problemy z tożsamością obejmujące m.in. jej kontestacje oraz kwestionowanie przypisanych powinności (Bokszański 2008).

Jednak paradoksalnie w dzisiejszym coraz bardziej dynamicznie zmieniającym się świecie punktem oparcia staje się stabilna i wyrazista tożsamość. Innymi słowy jest ona głównym źródłem sensu i doświadczenia współczesnego człowieka (Castells 2008). Indywidualna tożsamość zaczyna odgrywać kluczową rolę nie tylko w stabilizowaniu sytuacji jednostki w momentach kryzysu i doświadczeń granicznych, takich jak nieuleczalna choroba czy śmierć bliskiej osoby, lecz także w okresach przejściowych i akulturacji migrantów (Schwartz, Montgomery, Briones 2006). Migracja może być bowiem zdarzeniem krytycznym zmieniającym bieg życia jednostki i wywołującym głębokie zmiany, a co za tym idzie potrzebę osiągnięcia poczucia stabilności oraz dążenie do poszukiwania życiowych punktów oparcia i odniesienia. Mogą być one osadzone nie tylko w cechach osobowości jednostki, jej koncepcji siebie czy wyznawanych wartościach, lecz także w relacjach 
społecznych wiążących migrantów zarówno z krajem wysyłającym, jak i przyjmującym lub też opierać się na powiązaniach transnarodowych.

Niniejszy artykuł prezentuje spojrzenie na procesy adaptacji migrantów z perspektywy koncepcji społecznego zakotwiczenia, która zajmuje się procesami przystosowania się jednostek do zmian, uwzględniając jednocześnie role więzi społecznych oraz tożsamości w adaptacji i integracji migrantów. Wykorzystanie tej koncepcji pozwala jednak przezwyciężyć ograniczenia związane z pojęciem tożsamości definiowanej subiektywnie, gdyż włącza do analizy czynniki obiektywne i zewnętrzne z nią związane (Grzymała-Kazłowska 2015).

Celem prezentowanej w artykule analizy było zidentyfikowanie w spontanicznych i niezapośredniczonych przez badacza wypowiedziach przykładów społecznego zakotwiczenia, ukazanie, jak przebiegają mechanizmy budowy mentalnych kotwic, czyli punktów oparcia w okresie przejściowym i w czasie późniejszej adaptacji migrantów do nowego środowiska społeczno-kulturowego. Artykuł przedstawia wyniki analizy wypowiedzi opublikowanych w mediach społecznościo$w_{y c h}{ }^{2}$ w perspektywie porównawczej. Analizą objęte zostały blogi, fora i grupy dyskusyjne o tematyce migracyjnej prowadzone na Facebooku przez migrantów z Polski w Wielkiej Brytanii, czyli w warunkach olbrzymiego zróżnicowania etnicznego, narodowego i kulturowego. $\mathrm{Z}$ drugiej zaś strony analizie poddane zostały wypowiedzi publikowane w mediach społecznościowych przez migrantów z Ukrainy przebywających w Polsce.

Artykuł składa się z następujących części. Otwiera go prezentacja ram teoretycznych, czyli głównych założeń koncepcji społecznego zakotwiczenia. Następną część stanowią rozważania na temat problemów natury metodologicznej i etycznej pojawiających się w kontekście badań internetowych oraz opis metodologii przeprowadzonego badania niereaktywnego - jakościowej analizy treści. Dalej zaprezentowane zostało omówienie podstawowych charakterystyk internetowych mediów etnicznych ${ }^{3}$, z uwzględnieniem mediów społecznościowych, z których korzystają migranci z Polski w regionie West Midlands oraz migranci z Ukrainy mieszkający w aglomeracji warszawskiej, gdyż to w tych dwóch lokalizacjach wcześniej przeprowadzone zostało badanie terenowe ${ }^{4}$ Zasadniczą część artykułu

${ }^{2}$ Media społecznościowe zostały zoperacjonalizowane jako aplikacje bazujące na internetowych rozwiązaniach Web 2.0, które umożliwiają tworzenie i wymianę wygenerowanych przez użytkowników treści (Kaplan, Haenlein 2010), przekształcając komunikację w publiczny dialog (Dekker, Engbersen, Faber 2015). Definicja ta obejmuje zatem kanały internetowej komunikacji, w której uczestniczyć może wielu użytkowników jednocześnie (Boyd, Ellison 2008), wyłączając korespondencję prywatną przesyłaną za pomocą różnych aplikacji.

${ }_{3}$ Media etniczne będą tu rozumiane jako media tworzone dla i przez migrantów lub przedstawicieli mniejszości etnicznych (Matsaganis, Katz, Ball-Rokeach 2011).

${ }^{4}$ Badanie terenowe zostało przeprowadzone w ramach projektu Social Anchoring in Transnational Social Spaces (SAST) kierowanego przez dr Aleksandrę Grzymałę-Kazłowską, finansowanego ze środków Komisji Europejskiej (działania Marii Curie w ramach Programu People 7 Programu 
stanowi prezentacja wyników przeprowadzonej analizy wybranych blogów polskich i ukraińskich migrantów oraz dyskusji prowadzonych na forach i w grupach na Facebooku w kontekście pytania, jak migranci w sensie subiektywnym i obiektywnym ustanawiają punkty swojego życiowego oparcia w społeczeństwie przyjmującym oraz przestrzeniach transnarodowych.

\section{Ramy teoretyczne}

Wykorzystywana w prezentowanym badaniu koncepcja społecznego zakotwiczenia odnosi się do procesu przystosowywania się migrantów do nowego środowiska społeczno-kulturowego, łącząc zagadnienia tożsamości (przy uwzględnieniu wymiaru zarówno indywidualnego, jak i społeczno-kulturowego) z problematyką adaptacji jednostki i integracji społeczeństwa (Grzymała-Kazłowska 2015).

Społeczne zakotwiczenie definiowane jest jako poszukiwanie przez jednostkę istotnych dla niej punktów odniesienia i oparcia - kotwic, które pozwalają jej osiągnąć relatywną psychospołeczną stabilność w nowej otaczającej ją rzeczywistości, zapewniając podstawę psychologicznego i społecznego funkcjonowania (Grzymała-Kazłowska 2013). Co istotne, koncepcja ta uwzględnia czynniki obiektywne i zewnętrzne osadzające jednostkę w rzeczywistości społecznej (takie jak wygląd, dobra materialne, status prawny, posiadane dokumenty), dzięki czemu pozwala przezwyciężyć ograniczenia związane z pojęciem tożsamości definiowanej subiektywnie.

Analitycznie można wyróżnić rożne typy kotwic - od subiektywnych i wewnętrznych (wiążących się z cechami osobowości jednostki i jej koncepcją samej siebie, indywidualnie wyznawanymi ideami i wartościami oraz pamięcią jednostkową) do obiektywnych, a zarazem zewnętrznych (takich jak zasoby materialne czy dokumenty osobiste). Z punktu widzenia badań migracyjnych szczególnie ciekawe wydają się kotwice o mieszanym charakterze tkwiące $\mathrm{w}$ relacjach społecznych (jak role społeczno-zawodowe, pozycja w strukturze społecznej, przynależność grupowa) oraz kotwice osadzone w kulturze (m.in. języki, przekazy kulturowe, normy, obyczaje). Kolejną ważną osią podziału jest zorientowanie na kraj przyjmujący lub wysyłający. Otóż wyróżnić możemy kotwice podtrzymujące więź z krajem wysyłającym m.in. poprzez pielęgnowanie tożsamości narodowej i więzi

Ramowego FP7/2007-2013, REA grant $n^{\circ}$ 331421). W jego ramach przeprowadzono 40 indywidualnych wywiadów pogłębionych oraz kwestionariuszowych z poakcesyjnymi migrantami z Polski mieszkającymi w Birmingham i okolicach, czyli w regionie West Midlands oraz 40 indywidualnych wywiadów pogłębionych i kwestionariuszowych z migrantami z Ukrainy mieszkającymi w Warszawie i okolicach. Badaniem objęte zostały osoby w wieku 30-49 lat, które mieszkały w kraju przyjmującym od roku do 10 lat. Respondenci byli zróżnicowani pod względem statusu społeczno-ekonomicznego oraz sytuacji rodzinnej, przy czym z badania wyłączone zostały osoby, które posiadały partnera / partnerkę lub współmałżonka / współmałżonkę z kraju przyjmującego. 
wewnątrzgrupowych oraz $\mathrm{z}$ drugiej strony te, które są wytwarzane na emigracji i łączą migrantów z krajem przyjmującym, ułatwiając ich integrację. Nie możemy zapominać także o możliwości zakotwiczenia w zróżnicowanych, strategicznie wyobrażonych przestrzeniach transnarodowych.

Koncepcja społecznego zakotwiczenia uwzględnia zatem złożoność, równoczesność, a zarazem zmienność powiązań współczesnych migrantów. Cechą zakotwiczenia jest bowiem możliwość odłączenia się obiektu od punktu oparcia - rzeczywistego bądź wyobrażonego. Wiąże się z tym zjawisko odwrotne do omawianego powyżej zakotwiczenia, czyli odkotwiczenie (Grzymała-Kazłowska 2015).

\section{Ograniczenia badań prowadzonych przez Internet - uwagi metodologiczne i etyczne}

Prowadząc badania treści publikowanych w Internecie, należy liczyć się z tym, że przez pozorną anonimowość, jaką daje sieć, analizowane wypowiedzi mogą być skrajnie pozytywne bądź negatywne. Anonimowość w sieci, definiowana jako nieznajomość partnera interakcji i nieidentyfikowalność (Mazurek 2006a: 84), może rodzić bowiem przekonanie o braku sankcji lub o ich mniejszym znaczeniu w przypadku złamania norm obowiązujących w codziennym życiu.

Należy jednak zwrócić uwagę także na pozytywne strony odczuwanej w sieci anonimowości. Sprzyja ona bardziej spontanicznej ekspresji osobistych przekonań oraz prezentacji skrywanych aspektów własnej osoby, które mogłyby nie spotkać się $\mathrm{z}$ akceptacją w najbliższym otoczeniu (Bargh, McKenna, Fitzsimons 2002). I mimo że część badaczy kładzie nacisk na słaby związek tożsamości offline i online, opisując Internet jako laboratorium służące eksperymentowaniu z własną tożsamością i sposobami autokreacji (Turkle 1995; Mazurek 2006b), to jednak liczne badania wykazują, że ludzie częściej pokazują w sieci cechy swojego prawdziwego ja (Krejtz, Krejtz 2006: 109). Co więcej, cyberprzestrzeń jest na tyle zróżnicowana, że umożliwia nie tylko kreację postaci, jaką chce się odgrywać, lecz także dokonanie próby utrzymania lub odzyskania wewnętrznej spójności i stworzenia poczucia przynależności poprzez odnalezienie wspólnoty podobnych do siebie ludzi (Mazurek 2006b; Olcoń-Kubicka 2009). Internet skłania do większej otwartości i bliskości emocjonalnej z innymi, a jednocześnie nie pozbawia poczucia prywatności (Ben-Ze’ev 2003). Daje też poczucie kontroli nad prezentowanymi cechami własnej osoby nawet w przestrzeni, w której dotychczasowa struktura i hierarchia zostają zawieszone.

Nie możemy jednak traktować autoprezentacji w sieci m.in. na blogach jako dosłownego relacjonowania rzeczywistości, lecz raczej jako wyrażanie wartości, motywacji i aspiracji ich autorów (Cichocki, Jędrkiewicz, Zydel 2012: 207). Tym bardziej, że blog stanowi formę dialogu z czytelnikami, którzy poprzez komentarze 
mogą wpływać nie tylko na treść kolejnych wpisów, lecz także utwierdzać skonstruowaną przez autora tożsamość lub ją negować (Olcoń-Kubicka 2006a: 154). $\mathrm{W}$ związku z tym blog określić można jako narzędzie wytwarzania tożsamości poprzez ekspresję i prowadzony z czytelnikami dialog.

Kolejnym ograniczeniem pojawiającym się w badaniach prowadzonych przez Internet jest brak informacji dotyczących charakterystyk społeczno-demograficznych osób badanych (Galasinska 2010). O ile w przypadku blogów i wideoblogów po prześledzeniu ich treści zazwyczaj można ustalić podstawowe informacje o ich autorach, o tyle w przypadku użytkowników forów często jest to niemożliwe. Problemem bywa niekiedy nawet próba ustalenia płci internautów, gdyż język polski daje możliwość ukrycia skojarzonego z nią rodzaju gramatycznego. Co więcej, nie wszystkie portale wprowadzają konieczność rejestracji w celu skorzystania $\mathrm{z}$ forum czy grupy dyskusyjnej. A nawet jeśli rejestracja i utworzenie konta są konieczne, to nie ma możliwości weryfikacji autentyczności podanych danych.

W kontekście reprezentatywności badań internetowych nie można zapominać także o zjawisku znanym jako podział cyfrowy - digital divide, polegającym na nierównym dostępie do nowych technologii, który prowadzi do społecznego i ekonomicznego wykluczenia, pogłębiając tym samym już istniejące nierówności (Batorski 2005). Początkowo badacze skupiali się na samym nierównym dostępie do globalnej sieci ${ }^{5}$ i nowych technologii (DiMaggio i in. 2001; Norris 2001). Jednak wraz z upowszechnieniem dostępu do Internetu zaczęto zwracać uwagę na kolejne wyłaniające się bariery i wymiary zróżnicowania, m.in. na szybkość i jakość połączenia czy też umiejętność korzystania z sieci (DiMaggio i in. 2004; Warschauer 2004).

Niezmiernie istotny staje się też tzw. cyfrowy podział drugiego rzędu, czyli umiejętność efektywnego wykorzystania nowych technologii oraz korzyści i szans życiowych, jakie daje dostęp do Internetu. Umiejętności te obejmują nie tylko zdolność sprawnego wyszukania informacji, lecz także ocenę ich przydatności i wiarygodności, następnie zdolność odpowiedniego ich wykorzystania, umiejętność nawiązywania kontaktów w sieci i uzyskania pomocy od innych jej użytkowników oraz możliwość bycia nadawcą i dotarcia $\mathrm{z}$ własnymi treściami do innych osób (Hargittai, Hsieh 2013), co jest szczególnie istotne w kontekście prezentowanych $\mathrm{w}$ niniejszym artykule analiz. W przypadku tworzenia i udostępniania w Internecie autorskich treści nie możemy zapominać także o motywacjach internautów - mimo dostępu do nowych technologii nie wszyscy użytkownicy sieci są zainteresowani takimi aktywnościami, jak zamieszczanie postów czy dzielenie się

${ }^{5}$ Dane International Telecommunication Union z 2014 r. wskazują na utrzymujące się zróżnicowanie w dostępie do sieci. Znaczące różnice widoczne są m.in. między Wielką Brytanią (odsetek osób w wieku 16-74 lata korzystających z Internetu wynosił 91,61\%) Polską (66,6\%) i Ukrainą $(43,40 \%)$. 
filmami bądź zdjęciami własnego autorstwa ${ }^{6}$. Dotychczasowe badania pokazują, że wyszczególnione wymiary zróżnicowania pokrywają się ze sobą - osoby młodsze o wyższym statusie społeczno-ekonomicznym mają większe szanse na posiadanie lepszej jakości dostępu do Internetu, a jednocześnie posiadają większe umiejętności korzystania z sieci, wykorzystując ją przede wszystkim w celach instrumentalnych (jako źródło informacji, kontaktów społecznych, pomocy) oraz twórczych, a nie wyłącznie jako źródło rozrywki (Hargittai, Hsieh 2013).

Mimo wielu przedstawionych powyżej ograniczeń związanych z reprezentatywnością badań internetowych mają one pewne zalety, zwłaszcza w przypadku metod badań jakościowych, którymi objęte są społeczności rozproszone, takie jak migranci. Należy tu wymienić chociażby wykorzystaną $\mathrm{w}$ prezentowanym badaniu analizę treści zastanych obejmujących m.in. narracje migrantów publikowane w mediach społecznościowych. I mimo że coraz częściej mówi się o wykluczeniu pewnych grup lub o procesach nowej dominacji użytkowników o określonych umiejętnościach (Brownlow, O’Dell 2002), to w przypadku migrantów możemy raczej mówić o inkluzyjnej roli mediów społecznościowych, takich jak fora, grupy dyskusyjne czy różnego rodzaju blogi. Nie bez znaczenia pozostaje bowiem fakt, że są to asynchroniczne formy komunikacji. A zatem nawet mniej biegli użytkownicy mają czas na zapoznanie się z publikowanymi treściami, zastanowienie się nad odpowiedzią czy komentarzem, a następnie ich opublikowaniem. Ich głosy mogą zatem zostać zauważone przez innych użytkowników (Mitra 2001; Norris 2002).

Na koniec warto jeszcze przypomnieć, że wykorzystanie treści i informacji dostępnych w sieci budzi wątpliwości natury etycznej przede wszystkim ze względu na dyskusyjną ocenę granic między tym, co publiczne, a tym, co prywatne. Część badaczy, prowadząc badania przez Internet, stała na stanowisku, że jest on miejscem ogólnodostępnym, a wypowiedzi internautów w automatyczny sposób stają się częścią publicznego dyskursu, a co za tym idzie - dostępnymi danymi (Denzin 1999). W związku z tym nie ma potrzeby wcześniejszego uzyskiwania zgód od osób publikujących wpisy w sieci, czy też ujawniania się jako badacz w sytuacji prowadzenia badania w zamkniętych grupach dyskusyjnych.

Drugie podejście opiera się na założeniu o dualistycznym charakterze przestrzeni internetowej, w której podział na sferę prywatną i publiczną nie ma zastosowania. Ludzie korzystający z forów i grup dyskusyjnych nie muszą przecież traktować tych form aktywności jako poszukiwania publicznej widoczności jak

${ }^{6}$ W Polsce w ciągu ostatniej dekady odsetek osób, które regularnie tworzą i udostępniają w sieci autorskie treści, modyfikują własne strony WWW lub prowadzą blogi, utrzymywał się na tym samym poziomie (7-8\%). Podobnie jest w przypadku uczestniczenia w grupach lub forach dyskusyjnych - od 2011 r. regularne korzystanie z nich deklarowało od $11 \%$ do $14 \%$ osób powyżej 16 roku życia (Batorski 2015). W Wielkiej Brytanii na stałym poziomie utrzymuje się pisanie bloga bądź prowadzenie własnej strony WWW (ok. 20\% internautów). Z możliwości umieszczania postów korzysta 33\% użytkowników Internetu (Dutton, Blank, Groselj 2013). 
w przypadku uczestnictwa w różnego rodzaju zgromadzeniach publicznych (wiecach czy manifestacjach), których istotą jest widoczność (Eysenbach, Till 2001). Wręcz przeciwnie: użytkownicy tego typu mediów mogą być przekonani o anonimowości, zwłaszcza w przypadku niewielkich grup, w których wymagana jest rejestracja, np. w grupach wsparcia.

$\mathrm{Z}$ drugiej strony obserwować możemy proces prywatyzacji strefy publicznej poprzez wprowadzenie do niej „dyskursów prywatnych” (Olcoń-Kubicka 2006b: 268). Na forum publicznym można dawać wyraz swoim indywidualnym problemom, opowiadać o kwestiach prywatnych, niekiedy wręcz intymnych. Dlatego też coraz częściej o zachowaniu w sieci mówi się jako o publicznie prywatnym, kiedy tożsamość użytkownika jest jawna, lecz dostęp do informacji o nim, czyli do jego postów czy filmów, jest ograniczony, lub prywatnie publicznym - kiedy dostęp do publikowanych treści jest otwarty, lecz autor ujawnia niewiele informacji na swój temat (Lange 2007). Dodatkową osią podziału jest funkcjonująca w sieci opozycja prywatności i twórczości (Batorski, Olcoń-Kubicka 2006). W badaniach społecznych nadrzędna wydaje się zasada ochrony prywatności badanych. Jednak w przypadku traktowania materiałów zastanych jako twórczości zasada ta może tracić na znaczeniu, gdyż internauci woleliby, aby przy ich cytowaniu było podane dokładne źródło.

Uzyskiwanie świadomej zgody autorów treści publikowanych w Internecie staje się problematyczne nie tylko $\mathrm{w}$ przypadku materiałów traktowanych jako twórczość. Pytania o to, w jaki sposób badacz powinien ujawnić się, aby nie zaburzyć dynamiki badanego środowiska, oraz w którym momencie zwrócić się z prośbą o wykorzystanie materiałów, dotyczy także badań prowadzonych w blogosferze oraz wszystkich rodzajach forów i grup dyskusyjnych. Część badaczy stoi na stanowisku, że z pytaniem o możliwość zacytowania wypowiedzi należy zwrócić się indywidualnie do wszystkich autorów, których posty chce się wykorzystać w przygotowywanej publikacji (Sharf 1997). Niejednokrotnie jest to jednak niemożliwe, ponieważ badacz nie dysponuje danymi kontaktowymi do wszystkich użytkowników danego medium. Dodatkowym problemem mogą okazać się zablokowane lub skasowane konta na forach oraz nieaktualne skrzynki mailowe. Co więcej, praktyka zwracania się z prośbą o zgodę do wszystkich użytkowników danego forum czy grupy w przypadku mediów cieszących się dużą popularnością jest niezwykle czasochłonna - do tego stopnia, że może uniemożliwić realizację badania.

Dosyć ogólnych wskazówek w tej sprawie dostarczają rekomendacje wypracowane przez organizacje zrzeszające badaczy internetowych, np. Association of Internet Researchers (Ess 2002; Markham, Buchanan 2012), jak również Kodeks etyki socjologa uchwalony przez Walne Zgromadzenie Delegatów Polskiego Towarzystwa Socjologicznego w 2012 r., którego wzorzec stanowił korpus dobrych praktyk i zasad etycznego postępowania wypracowany przez British Sociological Association (Polskie Towarzystwo Socjologiczne 2012; British Sociological Association 2002). 
Dokumenty te mówią jedynie o wymogu szczególnej staranności w trakcie prowadzenia badań przez Internet oraz ostrożności w formułowaniu sądów mogących wpływać na dobrostan osób badanych w sieci.

\section{Metodologia badania}

Przeprowadzone badanie - analizę treści wybranych forów, grup dyskusyjnych i blogów - zaklasyfikować można jako badanie niereaktywne, czyli takie, które nie wpływa na analizowane zachowania społeczne (Babbie 2006: 341). W tym przypadku byłaby to ingerencja w naturalny tok prowadzonych dyskusji oraz spontanicznych narracji migrantów. Wypowiedzi internautów ograniczone mogą być wprawdzie przez regulaminy danego forum czy też grupy dyskusyjnej, oparte na netykiecie, czyli zbiorze zasad przyzwoitego zachowania w sieci. Warto jednak podkreślić, że wykorzystując analizę treści, unika się sytuacji, która pojawiać się może podczas wywiadu, kiedy to pewne kategorie są sugerowane czy wręcz narzucane przez badacza.

Dane wykorzystane w prezentowanym badaniu zostały zebrane przy uwzględnieniu wszystkich kwestii natury metodologicznej i etycznej wymienionych we wcześniejszej części artykułu. Punktem wyjścia przy wyborze blogów były kryteria doboru respondentów w badaniu SAST, którym objęci zostali migranci z Polski w Wielkiej Brytanii i z Ukrainy w Polsce w wieku 30-49 lat przebywający w tych krajach od roku do 10 lat. Z badania wyłączone zostały osoby, które były w związkach formalnych lub nieformalnych z obywatelami państw przyjmujących. W związku z powyższym po wstępnym badaniu, polegającym na zidentyfikowaniu blogów ${ }^{7}$ i wideoblogów prowadzonych przez polskich migrantów na Wyspach i ukraińskich migrantów przebywających w Polsce, dokonano dalszej selekcji internetowych pamiętników na podstawie przedstawionych powyżej kryteriów oraz prezentowanych na blogach treści. Do analizy zostały wybrane te, które opisywały osobiste doświadczenia autorów związane z podjętymi migracjami, były prowadzone regularnie przez co najmniej rok, a publikowane wpisy stanowiły przede wszystkim rozbudowane narracje. Następnie do autorów blogów zwrócono się $\mathrm{z}$ informacją o celach prowadzonego badania oraz z prośbą o wyrażenie zgody na wykorzystanie do analizy publikowanych przez nich treści, a także cytowanie wypowiedzi w przygotowywanej publikacji. Dwóch blogerów (jeden emigrant z Polski i jeden z Ukrainy) w odpowiedzi poprosiło o podawanie źródła wypowiedzi przy ich cytowaniu we wszelkiego rodzaju publikacjach. W związku z powyższym w prezentowanej analizie cytaty pochodzące $\mathrm{z}$ ich blogów zostały opatrzone informacją, z jakiego źródła pochodzą. Cytaty z kolejnych dwóch blogów wykorzystanych

\footnotetext{
${ }^{7} \mathrm{Z}$ badania wyłączone zostały mikroblogi ze względu na ograniczenia długości publikowanych komunikatów.
} 
w analizie (prowadzonych przez dwie emigrantki: jedną z Polski i jedną z Ukrainy) zostały zakodowane przy zachowaniu zasad anonimowości. Są one jedynie opatrzone kodem informującym o dacie wypowiedzi oraz kraju pochodzenia autorki. Natomiast komentarze czytelników pojawiające się pod wpisami na blogach zostały uwzględnione jedynie w analizie ogólnego kontekstu tworzonego dyskursu, lecz nie były poddane kodowaniu i przytaczane jako cytaty.

W przypadku forów i grup dyskusyjnych, podobnie jak w przypadku blogów, pierwszy etap badania stanowiło zidentyfikowanie najpopularniejszych etnicznych mediów internetowych (w tym mediów społecznościowych), z których korzystają polscy migranci w Wielkiej Brytanii oraz migranci z Ukrainy w Polsce. Celem było dotarcie do wypowiedzi osób przebywających już na emigracji, a nie jedynie przygotowujących się do wyjazdu lub niebiorących pod uwagę emigracji. Dlatego zrezygnowano z możliwości analizowania zawartości popularnych forów o tematyce migracyjnej tworzonych na portalu Gazeta.pl, którego regulamin pozwala na wykorzystywanie i cytowanie materiałów na nim umieszczonych pod warunkiem podania źródła.

W związku z nasyceniem rynku mediów polskojęzycznych w Wielkiej Brytanii poszukiwania były skoncentrowane na mediach przeznaczonych dla Polaków zamieszkujących region West Midlands, w którym wcześniej przeprowadzone zostało badanie terenowe $\mathrm{w}$ ramach projektu SAST. Z kolei w związku z niewielką liczbą mediów przeznaczonych dla migrantów z Ukrainy w Polsce poszukiwaniami objęte zostały zarówno media ogólnokrajowe, jak i wydawane na Ukrainie. Kolejnym ważnym kryterium była otwartość danej platformy. Innymi słowy, pod uwagę brane były wyłącznie te grupy i fora, które są dostępne dla wszystkich użytkowników sieci, a więc takie, które każdy internauta może czytać i na których może umieszczać swoje wypowiedzi. Następnie po zapoznaniu się z regulaminami poszczególnych forów i grup do ich administratorów zostały skierowane prośby o wyrażenie zgody na wykorzystanie publikowanych na nich treści w celach badawczych. W rezultacie jakościowej analizie poddane zostały tematy poświęcone życiu na emigracji publikowane na forach do końca sierpnia 2015 r.: MojaWyspa.co.uk, polsha24.com, chemodan oraz wpisy pochodzące z 2015 r. publikowane w grupach na Facebooku „Ukraińcy w Polsce” i „Polacy w Birmingham”.

Podobnie jak w przypadku blogów jednostkę analizy stanowił pojedynczy post, który mógł być rozbudowaną wypowiedzią lub składać się z pojedynczego słowa, a nawet emotikonu. Posty zostały zakodowane w programie Atlas.ti według wcześniej opracowanego klucza kodowego, który był wykorzystany na potrzeby analizy

${ }^{8}$ W przypadku mediów przeznaczonych dla emigrantów z Polski w Wielkiej Brytanii w pierwszej kolejności prośba o wykorzystanie w celach badawczych treści publikowanych na forum została skierowana do redakcji najpopularniejszego w regionie West Midlands portalu bham.pl, lecz administratorzy nie zgodzili się na ich wykorzystanie. 
wywiadów przeprowadzonych w pierwszej fazie projektu SAST. Posty z polskich forów i blogów były kodowane, a następnie cytowane przy zachowaniu oryginalnej pisowni. Natomiast posty ukraińskich migrantów zostały przetłumaczone na język polski z rosyjskiego i ukraińskiego i dopiero wówczas zakodowane. Wpisy pochodzące $\mathrm{z}$ forów i grup dyskusyjnych są przytaczane $\mathrm{w}$ niniejszym artykule jedynie jako przykłady wypowiedzi migrantów, dlatego nie zostały one opatrzone pseudonimem osoby je publikującej. W ten sposób starano się zachować zasadę anonimowości badanych.

Internetowe media etniczne wykorzystywane przez migrantów w krajach przyjmujących

Wśród użytkowników pochodzących z różnych krajów, czy też regionów, istnieją znaczące różnice w preferencjach dotyczących wyboru mediów, z których użytkownicy ci korzystają, zwłaszcza portali społecznościowych. Może to prowadzić do tworzenia równoległych, wirtualnych przestrzeni, które tylko w niewielkim zakresie nachodzą na siebie (Dekker, Engbersen 2014; Hargittai 2008). Dlatego też oddzielnie została przedstawiona charakterystyka internetowych mediów etnicznych, z których korzystają migranci z Polski w Wielkiej Brytanii, oraz internetowych mediów etnicznych, z których korzystają migranci z Ukrainy w Polsce.

\section{Media internetowe wykorzystywane przez migrantów z Polski} w Wielkiej Brytanii

Migranci z Polski w Wielkiej Brytanii mają do dyspozycji całe spektrum mediów etnicznych, w tym mediów o długoletniej tradycji sięgającej okresu II wojny światowej (Leonowicz-Bukała 2015). Korzystać mogą z elektronicznych wersji prasy polskojęzycznej (m.in. „Dziennik Polski”, „Cooltura Polish Weekly Magazine”, „Głos Polonii.com”, „Goniec Polski”, „Polskie Echo”, „Polish Express”, „Nowy Czas”), internetowych stacji radiowych („Polskie Radio Londyn”, „Radio Banita Maxx”, „Radio HeyNow”, „Radio Orła”, „Radio Star”, „Radio Moja Wyspa, Londyn UK”, „Radio Emi”, „Polskie Radio Oxford”), jak również z powstałych w ostatnich latach licznych portali internetowych o zróżnicowanych profilach - ogólnoinformacyjnych (ANGLIA.today, Nasze Wyspy - naszewyspy.co.uk, Twoja Anglia twojaanglia.co.uk), lokalnych (m.in. Bham.pl, Birminghampl.co.uk, Polonia West Midlands UK - mypolonia.co.uk), tematycznych, ogłoszeniowych, społecznościowych czy randkowych.

Co więcej, popularność Internetu jako źródła informacji wśród migrantów poakcesyjnych skłoniła największe polskie portale do uruchomienia specjalnych wersji serwisów przeznaczonych dla Polaków na Wyspach Brytyjskich (m.in. Onet. eu, Anglia.interia.pl, Poradnik Emigranta w ramach portalu GazetaPrawna.pl). 
Serwisy te były wzbogacone o lokalne materiały prasowe redagowane przez oddziały brytyjskie oraz o przegląd artykułów z prasy polonijnej, brytyjskiej i irlandzkiej.

Niesłabnącą popularnością cieszą się z kolei tzw. prywatne fora tworzone w serwisie Forum.gazeta.pl w kategorii tematów „Na emigracji”. Wszystkie one obejmują od kilkuset do kilkunastu tysięcy wątków, a co za tym idzie wiele tysięcy odpowiedzi użytkowników. Warto przy tym zauważyć, że fora zakładane w tym serwisie są popularne zarówno wśród osób, które zdecydowały się na emigrację, jak i wśród tych, które dopiero ją rozważają lub które przygotowują się do wyjazdu.

W kontekście migracji poakcesyjnych najciekawszy wydaje się jednak rozkwit mediów etnicznych powstałych niekiedy na gruncie agencji oferujących pomoc migrantom z Polski i stanowiących część przemysłu migracyjnego, czyli zbioru różnego rodzaju komercyjnych instytucji, które mogą czerpać zyski nie tylko z rosnącej mobilności migrantów, lecz także z ich efektywnej adaptacji do nowego środowiska (Garapich 2008: 736). Duża konkurencja na rynku polskojęzycznych mediów na Wyspach wymusiła upowszechnienie informacji o podstawowych prawach migrantów oraz rozmaitych formach pomocy. $\mathrm{Na}$ wszystkich stronach dostępne są bowiem tworzone na podstawie oficjalnych materiałów instytucji publicznych artykuły o charakterze poradnikowym, wzory wypełniania dokumentów oraz szczegółowe informacje o zasiłkach z pomocy społecznej. Michał Garapich stawia wręcz tezę, że żadna organizacja pozarządowa nie wspomogła integracji polskich migrantów w wymiarze prawno-instytucjonalnym w takim stopniu co nowo powstałe media etniczne (Garapich 2008: 744).

Przyczyniły się one do wytworzenia forum publicznego wykorzystywanego jednak nie tylko w celach instrumentalnych, takich jak szybkie zdobycie potrzebnych informacji czy możliwość zareklamowania prowadzonej działalności gospodarczej. Przestrzeń przez nie wytworzona traktowana jest bowiem także jako miejsce spotkań osób o podobnych doświadczeniach. Jest to kolejny sposób na spędzenie wolnego czasu. Świadczy o tym popularność forów i grup dyskusyjnych o profilu krajowym i lokalnym, na których nie tylko omawiane są kwestie dotyczące wynajmu mieszkań, znalezienia pracy czy transportu do Polski, lecz także prowadzone są dyskusje na rozmaite tematy ogólne oraz w pewien sposób zaspokajane potrzeby towarzyskie, m.in. poprzez poznawanie nowych użytkowników spoza najbliższego kręgu rodaków. W związku z tym najpopularniejsze portale łączą funkcje informacyjne i społecznościowe (m.in. Londynek.net, MojaWyspa.co.uk, Emito.net, Polemi.co.uk), integrując wewnętrznie środowisko polonijne na Wyspach i ułatwiając adaptację migrantów do społeczeństwa przyjmującego.

Co więcej, w wytworzonym przez media etniczne forum publicznym mogą uczestniczyć i zostać zauważone grupy wcześniej wykluczone i pozbawione głosu, np. ze słabą znajomością języka angielskiego czy podejmujące nielegalną pracę. Dzięki temu media etniczne odgrywają olbrzymią rolę w procesie kreowania i negocjowania tożsamości migrantów poakcesyjnych (Garapich 2008). 
Nieco inną funkcję niż portale informacyjne wraz z zintegrowanymi forami pełnią grupy dyskusyjne, tworzone przez migrantów z Polski mieszkających w Birmingham i okolicach w ramach największego serwisu społecznościowego, jakim jest Facebook ${ }^{9}$. Grupy te stanowią przede wszystkim darmowe tablice ogłoszeń wykorzystywane do zareklamowania oferowanych usług, produktów lub organizowanych imprez. W przypadku społeczności polskich migrantów można zatem mówić o „kompletności instytucjonalnej”, czyli wytworzeniu w miejscu osiedlenia podmiotów umożliwiających zaspokojenie wszystkich ich potrzeb w ramach własnej grupy etnicznej (Breton 1964).

Oprócz komercyjnych przedsięwzięć, takich jak profesjonalne portale i fora, kilka słów należy się blogom i wideoblogom, czyli oddolnym inicjatywom migrantów. Przede wszystkim zaskakuje ich ilość oraz zdominowanie tej sfery aktywności w sieci przez kobiety. W trakcie realizacji badania udało się zidentyfikować 81 blogów (działających oraz zamkniętych, lecz wciąż dostępnych w sieci, do których nie jest wymagane zaproszenie właściciela lub rejestracja), które podejmowały tematy związane z emigracją na Wyspy. Spośród nich aż 69 było prowadzonych przez kobiety, przy czym 24 należało do „Klubu Polek na Obczyźnie” - nieformalnej grupy założonej w 2013 r., zrzeszającej Polki piszące na emigracji (w sumie ponad 240 blogerek). Zapewne grono polskich blogerów na Wyspach jest jeszcze liczniejsze, lecz część autorów może koncentrować się na opisywaniu innych zagadnień niż kwestie związane z podjętymi migracjami, m.in. swoich zainteresowań i pasji. Warto też zwrócić uwagę na język dzienników - spośród zidentyfikowanych 81 blogów 6 pisanych było wyłącznie po angielsku, a kolejnych 6 po polsku i angielsku. W przypadku blogów dwujęzycznych zdarza się, że autorzy piszą notki w dwóch językach, a po nabyciu biegłości w posługiwaniu się angielskim decydują się na publikowanie postów głównie w tym języku.

Innym popularnym wśród emigrantów typem blogów są wideoblogi zwane inaczej vlogami ${ }^{10}$. Ich dokładną liczbę również trudno jest określić, ponieważ tylko część poświęcona jest wyłącznie zagadnieniom związanym z migracjami. Vlogi te stanowić mają rodzaj przewodników po obcym kraju - przedstawiać realia życia w Wielkiej Brytanii, m.in. ceny podstawowych produktów, rodzaje opłat komunalnych, procedurę rejestracji samochodu czy poszukiwania pracy. Sporą grupę bardzo popularnych kanałów tworzą vlogi emigracyjne, które w większym zakresie są relacjami z prywatnego życia ich autorek i autorów.

${ }^{9}$ Pomijam tu grupy działające w serwisie nk.pl (dawniej Nasza Klasa) ze względu na stały spadek zainteresowania portalem (od 2010 r. po wprowadzeniu nowego regulaminu), a co za tym idzie liczby jego użytkowników. W tym miejscu warto jedynie przypomnieć, że serwis ten odegrał olbrzymią rolę w rekonstrukcji sieci społecznych oraz tworzeniu sieci migranckich Polaków w Wielkiej Brytanii (White i Ryan 2008: 1491).

10 Vlogi te mają stale powiększające się grono odbiorców - od kilkuset subskrypcji kanału do ponad 150 tys. subskrybentów w przypadku jednego z najstarszych wciąż działających (stan na październik 2016 r.). 


\section{Media internetowe wykorzystywane przez migrantów z Ukrainy w Polsce}

Media etniczne skierowane do tej grupy migrantów, bazujące na internetowych rozwiązaniach, są relatywnie słabo rozwinięte. Migranci z Ukrainy w Polsce korzystać mogą zaledwie z kilku tytułów tworzonych z myślą o nich. Na początku należy wymienić portal Наш вибір (naszwybir.pl), który stanowi cyfrową, dwujęzyczną (polsko-ukraińską) wersję gazety „Nasz Wybór” wydawanej przez fundację o tej samej nazwie stworzoną przez migrantów z Ukrainy. Portal ten, poza publicystyką o kulturalnej, oświatowej i społeczno-politycznej tematyce, dostarcza również informacji o bieżących wydarzeniach na Ukrainie, a także porad na temat aktualnych rozwiązań instytucjonalno-prawnych, obowiązujących migrantów, którzy chcą osiedlić się i pracować w Polsce.

Ponadto tematykę ukraińską, a w zasadzie współpracy polsko-ukraińskiej, podejmuje dwujęzyczny portal PolUkr (polukr.net) o charakterze analityczno-informacyjnym oraz prowadzony po polsku portal informacyjny Wschodnik. pl (wschodnik.pl), zaś problematykę szeroko definiowanej Europy Środkowej i Wschodniej - serwisy o adresach: porteuropa.eu oraz rosjapl.info. Wątek dotyczący migrantów z Ukrainy pojawia się też sporadycznie w wydawanym od 60 lat przez Związek Ukraińców w Polsce tygodniku „Nasze Słowo”. W związku z tym trudno jest określić ten tytuł jako źródło informacji przeznaczone dla Ukraińców przyjeżdzających do Polski.

Natomiast spośród mediów internetowych przeznaczonych dla różnorodnych grup migrantów należy wymienić portal Kontynent - Warszawa Wielu Kultur (kontynent-warszawa.pl), prowadzony wyłącznie w języku polskim przez Fundację „Inna Przestrzeń” przy wsparciu finansowym Urzędu Miasta Stołecznego Warszawy oraz powiązany z nim serwis Infomigrator (info-migrator.pl) dostępny także w wersji ukraińskiej. Jego zadaniem jest dostarczanie kompleksowych informacji dotyczących kwestii formalnych i prawnych związanych z pobytem w Polsce oraz praktycznych wskazówek na temat różnych aspektów życia codziennego w poszczególnych polskich miastach.

Z kolei ilość grup dyskusyjnych i forów prowadzonych przez i dla ukraińskich migrantów w Polsce jest trudna do ustalenia. Trudności te spowodowane są przede wszystkim problemami w oddzieleniu źródeł rosyjskojęzycznych od tych zarejestrowanych jako rosyjskie, skierowanych lub w większości użytkowanych przez Rosjan. Zarówno pierwsze, jak i drugie mogą być bogatymi źródłami informacji, zaspokającymi potrzeby migrantów z Ukrainy, którzy zazwyczaj znają język rosyjski w stopniu pozwalającym na swobodną konwersację (Kulyk 2006). Nie bez znaczenia może pozostawać także świadomy wybór samych migrantów podyktowany względami pragmatycznymi - w języku rosyjskim są w stanie porozumieć się z większą liczbą użytkowników sieci oraz dotrzeć do większej ilości informacji. Ponadto część środowiska migrantów może ulegać zakorzenionemu 
na Ukrainie stereotypowi przypisującemu językowi ukraińskiemu „wiejski”, mniej prestiżowy charakter. Z drugiej strony przed wydarzeniami z 2013 r. posługiwanie się językiem ukraińskim w oficjalnych kontaktach było odbierane jako demonstracja niepodległościowych, proukraińskich i proeuropejskich poglądów (Kulyk 2006). Wybór języka wiązać się zatem może z pochodzeniem i statusem społecznym, poglądami politycznymi, wyznaniem oraz regionem, z którego pochodzi dany internauta.

Spośród forów na początku należy wymienić bardzo obszerne, w całości poświęcone emigracji forum Чемодан (forum.chemodan.ua) (z ros. чемодан [chemodan] 'walizka') przeznaczone przede wszystkim dla osób, które dopiero przygotowują się do wyjazdu. Znajduje się tam ok. 5 tys. tematów związanych z migracjami do Polski, jednak poświęcone są one w głównej mierze kwestiom formalno-prawnym, m.in. legalizacji pobytu oraz możliwościom podjęcia studiów w Polsce. Co istotne, językiem najczęściej spotykanym na forum jest język rosyjski, chociaż można tam znaleźć także wiadomości w języku ukraińskim. Pojedyncze wątki dotyczące migracji do Polski odnaleźć można także w serwisie Meta (meta.ua) - największym i najpopularniejszym portalu na Ukrainie. Znacznie częściej ukazują się tam posty będące ogłoszeniami zamieszczonymi przez firmy pośredniczące w znalezieniu pracy. Rosyjskojęzyczni migranci z Ukrainy korzystać mogą ponadto z forum działającego w ramach portalu Rosjanie.pl (rosjanie.pl) oraz strony POLSHA 24 (polsha24.com) - portalu informacyjnego rozwijanego przez polską firmę skoncentrowaną na promocji w rosyjskojęzycznym Internecie.

Funkcje platform służących wymianie informacji i prowadzeniu dyskusji przejęły za to grupy tematyczne tworzone $\mathrm{w}$ ramach mediów społecznościowych na Facebooku oraz w rosyjskojęzycznym serwisie WKontaktie (obecnie VK) ${ }^{11}$. W przypadku najliczniejszych grup na Facebooku oficjalnymi językami publikowanych postów oraz reklam są ukraiński, polski i angielski. Posty w języku rosyjskim lub innym są dopuszczone jedynie jako prywatne komentarze. Administratorzy, wśród których znajdują się znani w społeczności ukraińskiej w Warszawie aktywiści, zaznaczają w opisach, że wielokrotne naruszenie zasad związanych z używanym językiem skutkuje usunięciem z grupy. Dużą popularnością cieszą się jednak także otwarte grupy, w których komunikacja przebiega głównie w języku rosyjskim. Można zatem uznać ukraińskojęzyczne grupy na Facebooku za miejsce, w którym spotykają się odgórnie tworzone strategie konstruowania tożsamości, chociażby przez narzucenie języka komunikacji, z negocjowanymi oddolnie strategiami migrantów (De Fina 2013).

${ }^{11}$ W krajach byłego Związku Radzieckiego największą popularnością cieszą się wciąż rosyjskojęzyczne portale VK oraz portal Odnoklassniki.ru, początkowo zorientowany na poszukiwanie starych znajomych ze szkoły. W trakcie realizacji badania w ramach portalu VK działały 4 otwarte grupy dyskusyjne przeznaczone dla migrantów z Ukrainy w Polsce. Podejmowane tematy dotyczyły przede wszystkim legalizacji pobytu w Polsce i możliwości podjęcia legalnej pracy bądź studiów. 
Język rosyjski dominuje z kolei w serwisie YouTube - w prowadzonych przez migrantów kilkunastu wideoblogach. Vlogi te subskrybuje od kilkuset do kilkunastu tysięcy internautów, a na najpopularniejszych kanałach poszczególne filmy mają do kilku tysięcy wyświetleń. Komentarze pod filmami publikowane są przede wszystkim po rosyjsku. Zdarzają się jednak także komentarze po polsku publikowane przez polskich internautów. Większość kanałów została założona na początku 2015 r. lub później. Wideoblogi są prowadzone zarówno przez pojedyncze kobiety lub mężczyzn, jak i przez pary. Różne są też ich doświadczenia zawodowe: niektórzy pracują fizycznie, innych można określić jako profesjonalistów. W krótkich filmach vlogerzy opowiadają o swoich doświadczeniach związanych z migracją do Polski, przede wszystkim o legalizacji pobytu, poszukiwaniu mieszkania, pracy czy szkół dla dzieci, ale też ciekawych miejscach czy swoich obserwacjach związanych z różnicami kulturowymi między Polską a Ukrainą. Na niektórych kanałach pojawiają się ponadto rozmowy przeprowadzone $\mathrm{z}$ innymi migrantami.

Nieco wcześniej niż wideoblogi migranci zaczęli zakładać blogi. Zaskakuje jednak ich niewielka liczba oraz mało urozmaicona tematyka skoncentrowana na kwestiach związanych z legalizacją pobytu w Polsce i podjęciem zatrudnienia. $\mathrm{Na}$ zaledwie kilku pojawiają się tematy związane z osobistymi doświadczeniami migrantów. Spośród 9 zidentyfikowanych podczas badania blogów ${ }^{12}$ zaledwie 1 pisany był w języku ukraińskim.

\section{Społeczne zakotwiczenie a integracja migrantów}

Przeprowadzone badanie pokazało, że migranci w swoich wypowiedziach spontanicznie odnoszą się do takich kategorii, jak „bezpieczeństwo” oraz „poczucie stabilizacji", które stanowią najbardziej elementarne ludzkie potrzeby i w związku z tym muszą być zaspokojone w pierwszym rzędzie. Dotyczy to zarówno brytyjskiego, jak i polskiego kontekstu.

$\mathrm{W}$ analizowanych narracjach eksponowana była zarówno kluczowa rola bezpieczeństwa fizycznego, jak również poczucia bezpieczeństwa finansowego zapewnianego przez pracę zarobkową. Zarówno Polacy, jak i Ukraińcy definiowali się przede wszystkim w kategoriach dobrych pracowników, a stabilna praca pozwalająca na godne życie stanowiła dla nich wartość samą w sobie. Nie bez znaczenia pozostawały także możliwości rozwoju zawodowego i awansu, nawet jeśli nie oznaczał on spektakularnych sukcesów ze względu na ograniczenia na rynku pracy, jakie pojawiają się przed cudzoziemcami. Co więcej, dzięki stabilnej sytuacji finansowej migranci mogą pozwolić sobie na kupno mieszkania bądź domu, co stanowić może istotną i trwałą kotwicę w kraju przyjmującym. Daje im to poczucie bycia u siebie oraz jest próbą

12 Oddzielną grupę stanowią pojawiające się w blogosferze blogi studenckie. Jednak także tych nie ma zbyt wiele lub po opublikowaniu kilku wpisów są zawieszane. 
radzenia sobie z nieprzewidywalnością poprzez ograniczenie niepewności bliżej nieokreślonej przyszłości. Jednak, co istotne, możliwości tego typu zabezpieczenia opisywane były przede wszystkim przez polskich migrantów w Wielkiej Brytanii.

W kontekście punktów oparcia zapewniających poczucie bezpieczeństwa i stabilizacji nie można pominąć także warunków instytucjonalnych kraju przyjmującego. Ważną kotwicą łączącą migrantów z Polski z Wielką Brytanią oraz Ukraińców z Polską okazało się bowiem przejrzyste działanie instytucji oraz przewidywalność warunków instytucjonalnych. Podkreślana w narracjach migrantów z Ukrainy przejrzystość wiązała się z mniejszą korupcją w służbie zdrowia oraz różnego rodzaju instytucjach. Z kolei opisywana przewidywalność dotyczyła obok relatywnie stałych zasad funkcjonowania biurokracji także spraw związanych z codziennym życiem w nowym miejscu osiedlenia, takich jak chociażby punktualność komunikacji miejskiej czy relatywnie stały kurs walut i stałe ceny najczęściej kupowanych produktów.

W przypadku migrantów z Ukrainy ze względu na konieczność legalizacji pobytu na terenie Polski nie można pominąć także znaczącej roli zakotwiczenia instytucjonalno-prawnego, czyli posiadanych dokumentów oraz statusu prawnego w kraju przyjmującym. Z kolei w przypadku analizowanych narracji Polaków w Wielkiej Brytanii zakotwiczenie instytucjonalno-prawne dotyczyło nie tyle posiadanej rezydentury lub brytyjskiego obywatelstwa, ile otrzymywanej na Wyspach pomocy socjalnej obejmującej różnego rodzaju zasiłki czy ulgi podatkowe.

Kolejną ważną obiektywną i zewnętrzną kotwicę w kraju przyjmującym stanowią szkoły, do których uczęszczają dzieci migrantów. Nawiązywanie kontaktów z rówieśnikami przyśpiesza naukę języka, dzięki czemu ich aklimatyzacja w nowym środowisku przebiega stosunkowo sprawnie. Nauka języka okazuje się kluczowa także dla dorosłych migrantów, którzy na forach i w grupach dyskusyjnych podkreślają konieczność znajomości języka kraju przyjmującego nie tylko w kontekście poszukiwania pracy, lecz także nawiązywania satysfakcjonujących kontaktów towarzyskich i integracji.

W tym miejscu warto odnieść się do tego, w jaki sposób sami migranci rozumieją efektywną integrację. Przede wszystkim w wypowiedziach publikowanych na analizowanych forach i blogach dominuje podejście ujmujące integrację jako proces wymagający czasu i wieloetapowy. Naczelną zasadą wyłaniającą się z narracji migrantów jest zaś poszanowanie i przestrzeganie norm obowiązujących w kraju docelowym. Postawy takie można określić jako prointegracyjne, co obrazują poniższe wypowiedzi migrantów z Polski i Ukrainy:

\section{Przykład 1 - emigracyjnyblog.blogspot.com (listopad 2006)}

Jedna z najliczniejszych grup narodowościowych $w$ Wielkiej Brytanii sa Polacy, głównie dzięki „zręcznej” polityce gospodarczej kolejnych bulbońskich rządów. Z przerażeniem zauważam, że bardzo duża cześć rodaków przyjeżdża tu i od pierwszego dnia zaczyna 
tu budować małą Polskę. Nie staraja się zintegrować, nie interesuje ich poznanie bogatej kultury tego kraju, zwyczajów, humoru. (...) Od kiedy stare mądre powiedzenie „When in Rome do like Romans do." nie ma już zastosowania?

\section{Przykład 2 - Facebook UA (kobieta, lipiec 2015)}

Zgadzam się z ostatniq wypowiedzia. Jeśli przyjechaliście tu, to przywyknijcie do lokalnych zasad, a nie przywoźcie swoje. Nikt nikogo nie zmuszał tu przyjeżdżać, to nie ma co się skarżyć, że jest tu coś nie tak.

Ponadto, elementem preferowanej strategii użytkowników badanych forów i blogów jest nawiązanie kontaktów z przedstawicielami społeczeństwa przyjmującego, dzięki czemu szybciej może zachodzić proces internalizacji nowych wzorów zachowań, systemów norm, wartości i znaczeń obowiązujących w kulturze dominującej. Jednocześnie w przypadku polskich forów w Wielkiej Brytanii krytykowane są strategie oparte na budowaniu etnicznych enklaw poprzez zamieszkiwanie w dzielnicach zdominowanych liczebnie przez Polaków i ograniczaniu sieci kontaktów do innych migrantów z Polski. Warto jednak pamiętać o deklaratywności analizowanych wypowiedzi, które odbiegać mogą od rzeczywistych praktyk migrantów. Z kolei jako przykład omawianych wcześniej postaw posłużyć może poniższy cytat:

\section{Przykład 3 - forum PL (mężczyzna, grudzień 2012)}

Postrzegam takie szukanie swoich i osiedlanie się na kupie jako tworzenie polskiego getta czyli źródła lokalnych problemów społecznych i środowiska średnio asymilujacego się $z$ reszta narodowości i władzami.

Przytoczona powyżej wypowiedź ilustruje ponadto jeszcze jedną tendencję. Otóż wątki dotyczące pozytywnych aspektów różnorodności etnicznej i narodowej nie są mocno akcentowane w publikowanych w sieci wypowiedziach. W dyskusjach toczonych na forach widoczne jest raczej podejście oparte na biernej akceptacji zastanej rzeczywistości na zasadzie „można do tego przywyknąć”. Z drugiej strony migranci podkreślają, że należy być przygotowanym na różne aspekty zróżnicowania społecznego w Wielkiej Brytanii. Ich podejście można określić jako pragmatyczne, wyrażające się w następującej zasadzie: jeśli nowi migranci nie zaakceptują otaczającej ich różnorodności, nie będą w stanie sprawnie funkcjonować w nowych warunkach społeczno-kulturowych.

Z kolei wątek zróżnicowania kulturowego i etnicznego praktycznie nie istnieje $\mathrm{w}$ internetowych dyskusjach migrantów z Ukrainy przede wszystkim ze względu na niewielki jego stopień w polskim społeczeństwie. Pojawiają się za to zachęty do nawiązywania kontaktów z Polakami, aby przyśpieszyć i usprawnić adaptację w nowych warunkach, co ilustrować może poniższy przykład: 
Przykład 4 - sirko.org.ua (październik 2012)

Ponadto, jest jedna bardzo ważna kwestia, którą ludzie ignorują, zapędzając się w kozi róg - przystosowanie się do nowego środowiska. Często przez niezdolność do komunikowania się na dowolne tematy z Polakami ludzie zaczynaja szukać rodaków, a jeśli ich nie znajda, zamykaja się $w$ sobie, co skutkuje stresem i problemami psychicznymi. (...) Obowiązkowo szukajcie nowych znajomych wśród Polaków, którzy maja podobne do waszych poglady, zainteresowania, hobby, to pozwoli Wam poczuć się lepiej w nowym środowisku, pozbyć się stresu i ostatecznie poczuć się swojsko w Polsce.

Powyższa wypowiedź ukraińskiego blogera pokazuje również potencjalną pozytywną rolę różnego rodzaju zainteresowań oraz aktywnego sposobu spędzania wolnego czasu w zakotwiczaniu i integracji migrantów w kraju przyjmującym. Aktywności związane m.in. ze sportem lub działalnością artystyczną wytwarzają bowiem przestrzeń, w której można podszkolić język oraz nawiązać nowe znajomości wykraczające poza krąg rodaków.

\section{Społeczne zakotwiczenie w klasowo-etnicznych tożsamościach}

Kotwice tkwiące w relacjach społecznych, takie jak role społeczno-zawodowe, pozycja w strukturze społecznej czy przynależność grupowa związana z tożsamością społeczno-kulturową, wydają się najbardziej złożonym typem kotwic (Grzymała-Kazłowska 2013). Przeprowadzone badanie wykazało, że zarówno migranci z Polski w Wielkiej Brytanii, jak i migranci z Ukrainy osiedleni w Polsce zakotwiczają się mentalnie w „wyobrażonych wspólnotach”, konstruując złożone klasowo-etniczne formy tożsamości ${ }^{13}$, które stanowią ich punkty odniesienia w nowych warunkach społeczno-kulturowych. W dalszej części artykułu przedstawione zostaną mechanizmy towarzyszące tym procesom.

W przypadku Polaków w Wielkiej Brytanii jednym z punktów odniesienia w redefiniowaniu tożsamości, a zarazem tworzeniu zakotwiczającej ich w społeczeństwie przyjmującym „wspólnoty wyobrażonej”, są biali Brytyjczycy z niższych klas społecznych (w założeniu Anglicy), których spotykają na co dzień - w pracy, w sklepach lub w dzielnicach, tam gdzie mieszkają. W narracjach migrantów ich cechy przypisywane są większości brytyjskiego społeczeństwa i stawiane

${ }^{13}$ Niestety objętość niniejszego artykułu nie pozwala na przedstawienie rozważań teoretycznych dotyczących definiowania pojęcia „klasy społecznej” oraz toczącej się debaty między zwolennikami tradycyjnego ujęcia opartego na precyzyjnych wskaźnikach ekonomicznych (m.in. stosunku do środków produkcji, pozycji zawodowej) a twórcami tzw. kulturowego podejścia do analizy klasowej, uwzględniającego w większym stopniu kwestie tożsamości, stylu życia oraz wzorów konsumpcji (por. Bottero 2004). W niniejszym artykule przyjęte zostało najszersze rozumienie pojęcia klasy „utożsamiane z pozycją zajmowaną przez daną kategorię w systemie uwarstwienia lub w hierarchii społecznej" (Domański 2007: 67). 
w opozycji do cech przybywających na Wyspy Polaków. A zatem z narracji migrantów wyłania się nierzadko obraz niechlujnego, leniwego Anglika określanego często jako Angol, który nie chce podjąć edukacji bądź pracy, czy też zadbać o swoje najbliższe otoczenie. Natomiast polscy migranci przedstawiani są przede wszystkim jako pracowici, ambitni i zaradni pracownicy. Są to zatem cechy, których Anglicy w opowieściach migrantów nie posiadają lub które posiadają w znikomym stopniu. W narracjach tych podkreślana jest ponadto zdolność i chęć Polaków do adaptacji w nowych warunkach oraz przyjęcie dominujących norm kulturowych brytyjskiego społeczeństwa.

Kolejnymi istotnymi cechami polskiego emigranta eksponowanymi w analizowanych postach są zdolność do poświęcenia i odwaga. W pierwszej kolejności cechy te przejawiają się w decyzji o wyjeździe z ojczyzny, życiu z dala od najbliższych w nowym środowisku. Życie na obczyźnie określane jest jako skok na głęboką wodę, na który nie zdecydowałby się „typowy Anglik”, a nawet gdyby starczyłoby mu odwagi na taki krok, nie dałby sobie rady na „prawdziwej”, czyli zarobkowej emigracji. Aby zilustrować sposób, w jaki migranci z Polski konstruują złożone klasowo-etniczne tożsamości w odniesieniu do białych Brytyjczyków, warto przytoczyć cytat $\mathrm{z}$ forum:

\section{Przykład 1 - forum PL (mężczyzna, marzec 2009)}

Co do Anglików, to ogót nich jest spoko, tylko że leserzy $z$ większości $z$ nich sa niesamowici. Pracuje $z$ takimi w magazynie i ci agencyjni odpadaja masowo. Sa jacyśs tacy chudzi (nie sądzę, żeby większość z tych, którzy mają $180 \mathrm{~cm}$ wzrostu ważyła 60kg), mięśnie maja mniejsze, niż ja w wieku 10 lat (nie przesadzam, wychowałem się w małym miasteczku, a tam trochę się trzeba napracować fizycznie) i są bardzo mocno niedouczeni. Dlatego żadnej konkurencji dla nas stanowić nie mogą. Wielu z nich wręcz symulowato prace, a jak podchodzit do nich shift manager i zwracał uwage dlaczego nic nie robia, styszał zazwyczaj pytanie: „Who are you?”. Aż na zebraniu team leader wspomniat o takich przypadkach. Gdy zaczniemy opuszczać ten kraj masowo, wtedy oni dostana Pakistańczyków i zobacza co jest dla nich lepsze. Po rozmowie z kilkoma Anglikami z pracy, doszli do wniosku, że chyba my. Przynajmniej ich nie wysadzamy w powietrze, a benefitów też bierzemy znacznie mniej, niż emigranci z Azji i Afryki (gdzieś czytałem, że ponad 40\% z nich żyje z benefitów, a w przypadku Polaków 1\%).

Ważnym punktem odniesienia dla polskich migrantów, jak widać w powyższym poście, są także mniejszości etniczne i społeczności emigrantów w Wielkiej Brytanii. Poprzez porównania z nimi Polacy na Wyspach tworzą swoistą klasowo-etniczną hierarchię mniejszości oraz migrantów w brytyjskim społeczeństwie. Dwie nadrzędne kategorie to rasa oraz religia identyfikowana jednocześnie $\mathrm{z}$ kulturą. $\mathrm{Na}$ jednej z najniższych pozycji w tworzonej przez polskich migrantów hierarchii znajdują się migranci z Azji Południowej oraz muzułmanie tworzący najliczniejszą grupę etniczną i wyznaniową w Birmingham. Określani są oni w pogardliwy, 
często otwarcie rasistowski sposób. Polacy wykazują się tu wręcz nieskończoną kreatywnością. Na forach można spotkać zatem następujące określenia: „pakistańcy”, „ciapajska część”, „największe skupisko ciapactwa”, „muslimowo”, „arabusy”, „kolorowi”. Określenia te przeciwstawiane są kategorii „białych” - w założeniu Brytyjczyków - czy też szerzej definiowanej „białej okolicy”, w tym migrantom z Polski, co podkreśla ich bliskość z grupą dominującą.

W dyskusjach prowadzonych na forach grupom mniejszościowym zarzuca się brak chęci integracji ze społeczeństwem przyjmującym, tworzenie niebezpiecznych gett oraz fanatyzm religijny. Mniejszości te odbierane są jako zagrożenie dla bezpieczeństwa kraju - to z nimi identyfikowany jest terroryzm. Jednakże zagrożenie oznacza nie tylko akty przemocy, lecz także, jeśli nie przede wszystkim, dominację obcej kultury i religii. Narzucenie obcych skryptów kulturowych wiąże się chociażby $\mathrm{z}$ podkreślaną $\mathrm{w}$ publikowanych $\mathrm{w}$ sieci wypowiedziach inną pozycją i rolą kobiet.

Kolejnym elementem zaburzającym ład społeczny przez przedstawicieli mniejszości etnicznych i grupy migrantów o innym niż europejskie pochodzeniu, wyłaniającym się z narracji polskich migrantów, jest nadmierne wykorzystywanie czy wręcz oszukiwanie brytyjskiego systemu opieki społecznej. Z internetowych dyskusji polskich migrantów wyłania się obraz innych migrantów i mniejszości, dla których praca zarobkowa w odróżnieniu od Polaków nie stanowi wartości samej w sobie. W związku z tym starają się oni żyć na koszt państwa, korzystając z rozmaitych dodatków socjalnych i ulg, zasilając szeregi biernej zawodowo ludności.

Jak już wcześniej wspomniano, powtarzającym się wątkiem w internetowych rozmowach jest łączenie wysokich wskaźników przestępczości ze zróżnicowaniem etnicznym i skupiskami migrantów. Najgorszą opinią użytkowników polskich forów w Wielkiej Brytanii cieszą się dzielnice zamieszkiwane przede wszystkim przez osoby pochodzące z Indii, Pakistanu i Bangladeszu oraz osoby wyznania muzułmańskiego. Internauci nierzadko w otwarcie rasistowski sposób dopytują o skład etniczny poszczególnych osiedli. Zależy im na znalezieniu miejsc o niewielkim zróżnicowaniu etnicznym i rasowym.

Część nowo przybyłych poszukuje wprawdzie „polskich” enklaw stanowiących duże skupiska Polaków z rozbudowaną infrastrukturą przeznaczoną dla migrantów. Spotyka się to jednak z ostrą krytyką użytkowników forów przede wszystkim jako wyraz braku chęci zintegrowania się z brytyjskim społeczeństwem i nauki języka. Ponadto podnoszony jest wówczas wątek nie tyle przestępczości wśród emigrantów z Polski, ile „polskiej patologii”, jak określają bezdomnych i alkoholików widocznych na ulicach. Jednak to obecność mniejszości południowoazjatyckich oraz muzułmanów jest szczególnie akcentowana w kontekście rozmów o bezpieczeństwie w mieście, co ilustrować może poniższy cytat: 


\section{Przykład 2 - forum PL (mężczyzna, maj 2012)}

to jeszcze dodam od siebie, mam znajomych którzy mieszkaja w B. od bardzo dawna (>10lat) i różnych historii nasłuchałem się o tym mieście. Po pierwsze - największe skupisko ciapactwa - które ma dużo większe prawa od nas, co tym samym nauczyło ich niesamowitej zdolności wyłudzania kasy za wszystko. To że będziesz pomału jeździł po mieście niekoniecznie uchroni cię od przypadków kiedy ktoś specjalnie ci się podstawi pod maskę:-?:-?:-? Tam to się dzieje notorycznie, a często kolesie żyją tylko z tego żeby wyjać kasę. Nie mówię już o wgniotach albo zarysowaniach na parkingu. Tak wiec nie zdziw się.

Z kolei najbardziej zachwalanym i pożądanym miejscem do osiedlenia stają się dzielnice zamieszkałe przez białych Brytyjczyków z klasy średniej. Użytkownicy forów podkreślają bezpieczeństwo i spokój panujące w takich miejscach, bliskość dobrych szkół, ale też wyższe koszty życia ze względu na koszty najmu lub kupna nieruchomości oraz wysokie lokalne podatki. Zamieszkanie $\mathrm{w}$ takim miejscu oznaczać zatem może potwierdzenie osiągniętego statusu materialnego i awansu społecznego poprzez odseparowanie się od grup marginalizowanych, m.in. mniejszości etnicznych i grup migranckich.

W kontekście zakotwiczania w „wyobrażonych wspólnotach” warto omówić kolejne istotne zagadnienie, jakim jest poczucie przynależności do społeczności migrantów oraz wytwarzanie i podtrzymywanie więzi etnicznej. Funkcjonujące na wielu poziomach dyskursu opowieści o wzajemnej wrogości Polaków na obczyźnie (Garapich 2010) są widoczne także w internetowych dyskusjach migrantów poakcesyjnych. Mimo zmiany funkcjonowania na rynku pracy - wyjścia z szarej strefy, która w warunkach dużej konkurencji nie sprzyja współpracy wewnątrzgrupowej - polscy migranci w Wielkiej Brytanii wciąż deklarują niechęć i brak zaufania do rodaków. Ostrzegają przed polskimi współpracownikami, pracodawcami oraz dzielnicami, w których mieszka dużo Polaków, co obrazuje poniższy cytat:

\section{Przykład 3 - forum PL (mężczyzna, grudzień 2014)}

Możesz się przejechać na Polakach za granica, myśla gdzie tu oszukać, ukraść i by innemu nie było lepiej od niego, zazdrość i pycha, cwaniactwo, nie mówię że wszyscy, oczywiście jest multum świetnych rodaków np. na tym forum, ale wprowadzajac się na "polska dzielnie” nie unikniesz tych „złych” ..., unikaj też polskich pracodawców, supervisorów i managerów. .. to dopiero „szlachta”

Z opowieści tych wyłania się obraz nieuczciwego, zawistnego migranta, który nie jest skory do pomocy innym na obczyźnie, w związku z czym w kontakcie z nim należy zachować ostrożność. Dystansowanie się od pewnych grup Polaków jest widoczną strategią w narracjach polskich migrantów - chcą odseparować się od rodaków, którzy stanowią źródło wstydu dla pozostałych, psując opinię o Polakach swoim zachowaniem, m.in. brakiem etosu pracy, kultury osobistej, przejawiającej się chociażby w słownej agresji skierowanej do Brytyjczyków, wszelkiego rodzaju 
nieuczciwością (od oszukiwania rodaków po wyłudzanie zasiłków), nadużywaniem alkoholu czy nieznajomością języka angielskiego. Podkreślane są zatem różnice klasowe i edukacyjne w obrębie polskiej społeczności na Wyspach. Jednocześnie podtrzymywane są podziały w oparciu o przynależność do konkretnej fali emigracyjnej - powojennym migrantom, którym przypisuje się wysoki poziom kapitału kulturowego i społecznego, przeciwstawiane są zastępy nowo przybyłych w wysokim stopniu zróżnicowane pod tymi dwoma względami, co obrazuje poniższy przykład:

\section{Przykład 4 - forum PL (kobieta, październik 2007)}

Nie potrafię zrozumieć dlaczego powiedzenie „wstydzę się takiego zachowania” wywołuje tyle kontrowersji !!! Jestem Polka i nie wstydzę się tego (mam nawet polska flage przy imieniu w pracy i na szybie samochodu), ale wstyd mi za wszystkich tych, którzy przyjeżdzają mało tego że bez podstaw języka, to bez podstaw dobrego wychowania. Nie potrafię znieść wiecznie nadąsanych i niezadowolonych min, codziennych opowieści typu „angielscy debile, pier...angole itp. itd” !!! Wiem jak wszystkim może być ciężko bo sama tu jestem, ale nigdy za własna sytuacje nie obwiniałam innych. Według mnie wyjazd za granice jest aktem odwagi, ale przydałoby się niejednemu przypomnieć że nie jest tu sam i opinia niestety „się niesie”. Na koniec dodam że nie raz miałam okazje rozmawiać z ludźmi z tzw. przed(po)wojennej emigracji i też sa załamani faktem że opinia, pracowitego, uczciwego i na wysokim poziomie Polaka, tak drastycznie teraz się zmienia i to za sprawa paru nowo przybylych frustratów.

Brak deklarowanej solidarności grupowej przejawia się także w akcentowanej w wypowiedziach konkurencji, jaką tworzą nowo przybyli migranci. W warunkach brytyjskich konkurencja ta postrzegana bywa nie tylko w kategoriach dostępu do rynku pracy, lecz także możliwości otrzymania pomocy socjalnej. Dlatego osobom bez dobrej znajomości języka i z niskimi kwalifikacjami zawodowymi internauci zdecydowanie odradzają migracje na Wyspy. Podkreślają, że decydując się na wyjazd z kraju i podjęcie pracy za granicą, nie można liczyć na pomoc ze strony rodaków. Nieefektywną strategią jest także liczenie na znaczące wsparcie ze strony rodziny lub traktowanie pomocy socjalnej jako koła ratunkowego w przypadku problemów ze znalezieniem pracy bądź mieszkania. Należy jednak przypomnieć, że przedstawiane analizy dotyczą sfery wytwarzanego przez polskich migrantów dyskursu, a nie rzeczywistych praktyk, które mogą różnić się znacząco w stosunku do wypowiadanych na forum publicznym opinii. Już sam fakt popularności tego typu mediów oraz ich charakter, który nie sprowadza się wyłącznie do tablicy ogłoszeń, świadczy o tym, że migranci dążą do kontaktów z rodakami na obczyźnie, tworząc wyobrażoną wspólnotę.

Kolejnym wartym uwagi wątkiem w kontekście zakotwiczenia jest podkreślanie w narracjach Polaków na Wyspach klasowego zróżnicowania postaw wobec migrantów w obrębie społeczeństwa przyjmującego. W związku ze specyfiką brytyjskiej kultury, opartej na zasadach uprzejmości we wszelkich formach kontaktu, 
Brytyjczykom zarzuca się sztuczność czy wręcz fałszywość w zachowaniach wobec migrantów - niechęć skrywaną za wyuczoną grzecznością i pozorną otwartością. Z kolei otwarcie negatywne nastawienie wobec przybyszy przypisywane są przede wszystkim grupom wykluczonym, które migranci charakteryzują jako „wykluczające się na własne życzenie" - Brytyjczykom, którzy przedwcześnie kończą edukację, bezrobotnym, żyjącym na zasiłkach. A więc takim, dla których migranci ekonomiczni podejmujący zatrudnienie $\mathrm{w}$ drugorzędnym sektorze rynku pracy mogą stanowić konkurencję w dostępie nie tylko do pracy, lecz także do pomocy społecznej. Z kolei pozytywne nastawienie przypisywane jest brytyjskim przedsiębiorcom oraz klasie średniej korzystającej z usług Polaków. Jako przyczyny pojawiającej się niechęci przedstawicieli społeczeństwa przyjmującego użytkownicy forum wymieniają przede wszystkim masowy napływ Polaków po akcesji Polski do Unii Europejskiej oraz korzystanie przez nich z różnych form pomocy socjalnej, jak zasiłek rodzinny czy mieszkaniowy lub dodatek do niskiego wynagrodzenia.

Omawiając mechanizmy zakotwiczania polskich migrantów w Wielkiej Brytanii, warto na koniec podkreślić rolę poczucia sprawczości i samodzielnego radzenia sobie z przeciwnościami losu w konstruowaniu złożonych form tożsamości. Widoczne jest to w narracjach dotyczących zadowolenia z osiągnięć zawodowych, podjęcia studiów w obcym kraju czy realizacji planów dzięki własnej ciężkiej pracy jak w poniższym cytacie:

Przykład 5 - forum PL (kobieta, listopad 2007)

Mieszkamy w UK półtora roku i przez ten czas mieliśmy tyle problemów że pomyślałam o napisaniu ksiażki ( mur beton będzie nr 1 :-] ) a jednak nie chcę wracać, ogólnie nie tęsknie za Polska tylko za rodzicami. Tutaj nauczyłam się nie rozmyślać dużo a brać się za tzw. robotę i patrzyć kiedy moge wejść schodek wyżej, powoli, powoli i za 50 lat będę paniq manager jak w Polsce hi, hi:-]:-]:-]. Wszystko będzie dobrze, więcej humoru, mniej rozmyślania o sobie i swoim zagubieniu a więcej o tym co mogę osiagnać $i$ jak to zrobić bo tutaj mamy wielkie możliwości i dano nam szanse nie zmarnujmy jej!!! Buziaczki $i$ byle do przodu :-]:-]:-]:-]:-]:-]:-]:-]...

Należy jednak zwrócić uwagę na dwa przewijające się w tej narracji wątki. Pierwszy to czas, jakiego wymaga realizacja planów i zamierzeń, czy też osiągnięcie subiektywnie definiowanego sukcesu na emigracji. Drugi wątek to możliwości, jakie dostępne są wszystkim przybywającym na Wyspy migrantom - od edukacyjnych (możliwość podniesienia lub uzupełnienia kwalifikacji zawodowych, zdobycia dyplomu brytyjskiej uczelni) po zarobkowe (praca nawet poniżej posiadanych kwalifikacji umożliwia osiągnięcie finansowego bezpieczeństwa). W tym kontekście istotne wydaje się także przedkładanie własnej pracowitości i zaradności, czyli polegania przede wszystkim na sobie, nad pomoc, którą można uzyskać w państwowych instytucjach pomocy społecznej. Zasiłki i różnego rodzaju ulgi nie są 
powszechnie przedstawiane jako alternatywa dla podjęcia zatrudnienia, lecz jako forma wsparcia uczciwie pracujących podatników. Nie wiążą się zatem z poczuciem wstydu czy napiętnowania.

Podobne mechanizmy tworzenia samoidentyfikacji i budowania wyobrażonych wspólnot, choć w kontekście homogenicznego społeczeństwa bez widocznych mniejszości, które mogłyby stać się punktem odniesienia, obserwować można w publikowanych w sieci wypowiedziach migrantów z Ukrainy. Podkreślają oni swoją pracowitość niejako w kontrze do lenistwa czy lekceważącego podejścia do pracy Polaków, co obrazuje poniższy post:

\section{Przykład 6 - forum UA (mężczyzna, czerwiec 2015)}

Dzień dobry. Przeczytałem Pana wpis. Nie zgodzę się z Panem. Polacy wychodza na papierosa 10 tysięcy razy na dzień, pracuja leniwe, caty czas gadaja, a na nocnych zmianach - moga i zasnąć. Tak, przerwy sa formalnie 15-20 minut, ale wszyscy dlużej jedza, potem gadaja i potem pala, nie spieszac się zbytnio. Pracuje w zakładzie jak pan, chociaż całe życie na Ukrainie byłem pracownikiem biurowym. Wszystko zależy od pracy, nie ma tu bajki ani raju, ale pracując i myśląc głowa, można osiagnać to, czego się chce.

Z drugiej strony w internetowych dyskusjach ukraińskich migrantów przewija się wątek braku znaczących różnic kulturowych (w tym bliskości językowej) między Ukraińcami a Polakami, co ułatwia ich codzienne funkcjonowanie w nowych warunkach, a co za tym idzie - integrację. Kolejną kwestią wartą uwagi jest posiadanie polskiego pochodzenia oraz przyjęcia polskiego obywatelstwa. W pewnym zakresie staje się to źródłem sporów w obrębie społeczności migrantów z Ukrainy w Polsce, gdyż według ukraińskiego prawa nie można posiadać dwóch paszportów. Przyjęcie polskiego obywatelstwa powinno zatem wiązać się z oficjalnym zrzeczeniem się obywatelstwa ukraińskiego, co wywołuje spore emocje wśród migrantów widoczne w cytowanym poniżej fragmencie dyskusji:

\section{Przykład 7 - Facebook UA (mężczyzna, maj 2015)}

Widzę z komentarzy, że Pani ma typowa chorobę lokalnych Ukraińców czy Polaków ukraińskiego pochodzenia - bo tak sobie chyba życzycie mówić. To nie odnosi się do wszystkich, ale do wielu.

\section{Przykład 8 - Facebook UA (kobieta, maj 2015)}

Dlaczego od razu taka agresja? Mówię, że nauczyłam się polskiego bez kursu i znam go biegle, tak że Polacy nie mogq odróżnić. Jestem dumna, że jestem Ukrainką i nie zamierzam przyjmować obywatelstwa [polskiego - przyp. autora], jak niektórzy... Wszystkiego Wam najlepszego i radzę pozbyć się niechęci i złości.

Sytuację bez wątpienia komplikuje zróżnicowanie w obrębie samej społeczności migrantów z Ukrainy w Polsce. Obejmuje ona bowiem m.in. osoby o mieszanych, 
złożonych formach tożsamości, jak chociażby te, dla których istotne, symboliczne znaczenie mają posiadane polskie korzenie.

Kolejnym istotnym wątkiem w kontekście społecznego zakotwiczenia migrantów jest eksponowanie znaczenia wartości, które utożsamiane są nie tyle z Polską, ile z Europą - praw i wolności obywatelskich, uczciwości, przejrzystości, demokracji, praworządności, braku korupcji. W związku z tym piętnowane są próby łamania porządku opartego na tych wartościach w kraju przyjmującym, jak chociażby jazda na gapę czy unikanie płacenia mandatów. Pojawiają się argumenty, obecne m.in. w cytowanych poniżej postach, mówiące o tym, że są to praktyki łamiące reguły zachowania „dobrego gościa” w kraju przyjmującym, a co za tym idzie godzą w reputację całej grupy.

Przykład 9 - Facebook UA (mężczyzna, sierpień 2015)

Ot jaka młodzież przyjechała, i ta sama młodzież pisze jak jej potrzebna jest Europa. Jesteśmy tu gośćmi, nie właźmy z butami na stót!

\section{Przykład 10 - Facebook UA (mężczyzna, sierpień 2015)}

Może i nie święci, ale ja na pewno bym tak nie robił, będąc w gościach w innym państwie próbować okłamać to państwo raz i próbować zrobić to jeszcze drugi raz i to otwarcie.

W przypadku migrantów z Ukrainy - w odróżnieniu od polskich migrantów na Wyspach - nie możemy jednak mówić o praktykach dyskursywnych opartych na dystansowaniu się od rodaków poprzez powielanie opowieści o wzajemnej wrogości i nieuczciwości na obczyźnie. Opinie takie, nawet jeśli funkcjonują wśród migrantów, nie są wyrażane wprost przez użytkowników forów i grup dyskusyjnych.

W analizowanych narracjach Ukraińców podkreślana jest za to ogólna nieufność i nieprzygotowanie polskiego społeczeństwa na spotkanie z ,innymi”, a czasami wręcz otwarta niechęć wobec obcokrajowców, szczególnie z państw powstałych po rozpadzie Związku Radzieckiego. Związane jest to m.in. z obawami Polaków dotyczącymi możliwej konkurencji na rynku pracy. Dotyczy to jednakże innych sektorów niż usługi domowe. Ukraińcy zwracają ponadto uwagę, że nie wszyscy polscy pracodawcy są gotowi na zatrudnianie cudzoziemców. Co więcej, migranci z Ukrainy spotykają się jeśli nie z negatywnym nastawieniem, to z lekceważeniem i protekcjonalizmem w sytuacjach nieformalnych, a także w polskich urzędach i kontaktach ze służbą zdrowia, co obrazuje poniższy cytat:

\section{Przykład 11 - Facebook UA (kobieta, sierpień 2015)}

Miałam wrażenie że dla polskich lekarzy jesteśmy ciekawymi przypadkami, bo nie pochodzimy stad. Polacy zawsze wymawiaja moje imie po kilka razy (...) Wtedy następne pytanie: skąd jestem? Z nieufnością: Ile czasu? Czy pracuje? Gdzie? I niby oczekuja że powiem, opuszczajac oczy: „Pracuję tak jak wszyscy, czyli sprzatam”. I oczekuja, że będe im proponować swoje ustugi. Kiedy mówię, że jestem dziennikarką, to nieufność 
zmienia się $w$ zdziwienie. Kiedy opowiadam historie swojej choroby, gdzie wspominam że miałam dużo stresu, szczególnie zima podczas obrony pracy doktorskiej, to zdziwienie znowu przerasta $w$ nieufność: „Taka młoda i już doktorat?”, „A czy w Polsce Pani ten doktorat robiła?”, „Nie, w Ukrainie,” $i$ wtedy zadowolony wyraz twarzy, bo wśród Polaków uważa się to za mniej warte powagi niżeli zrobione w Polsce.(...) U ukraińskich lekarzy po prostu mówię co mnie boli, a tu czuje sie jakbym musiała przedstawić jeszcze jakieś dowody, że jestem człowiekiem i tylko wtedy mówić, co mnie boli. Najgorsze jest to, że lubię Polskę, komfortowo mi się tu mieszka i chyba dlatego jestem tak wyczulona na to, że ktoś mi przypomina że nie do końca jestem tu swoja. Przypomina mi się dziś piosenka ukraińskiej grupy Talita Kum „Wszędzie jesteśmy obcokrajowcami, na lotnisku, w metrze, na ulicy...” Tak, nawet tam, gdzie czujesz sie prawie jak w domu, ale jak mawia mój ojciec, „prawie” się nie liczy.

Jak widać w powyżej obszernie cytowanej wypowiedzi podejście Polaków do migrantów z Ukrainy oparte jest na stereotypach dotyczących profilu prac przez nich wykonywanych. Traktowani są oni przede wszystkim jako migranci zarobkowi niezależnie od motywów przyjazdu do Polski. Szczególnie widoczne jest to w narracjach kobiet - przypisuje się im zazwyczaj pracę w sektorze usług domowych, a słowo „Ukrainka” stało się synonimem pomocy domowej i sprzątaczki. Takie nastawienie Polaków (niezależnie od ich pozycji społecznej) odbierane jest jako upokarzanie Ukraińców i słowna agresja. Migranci z Ukrainy wtłaczani są zatem w etniczne ramy, w których znoszone są wszelkie różnice związane z pozycją społeczno-ekonomiczną. Jednym z mechanizmów obronnych może być w tej sytuacji podkreślanie zdobytego wykształcenia i osiągniętej pozycji na rynku pracy w kraju przyjmującym.

\section{Dyskusja wyników}

Wyniki przeprowadzonego badania wskazują na kluczową rolę poczucia bezpieczeństwa i stabilizacji w procesie integracji i zakotwiczenia migrantów w nowym kraju, zarówno w przypadku migrantów z Ukrainy, jak i z Polski. Należy oczywiście pamiętać o specyfice mediów, z których pochodzą analizowane posty. Treści internetowe odwołujące się do emocji lub o sensacyjnym charakterze i dosadności przekazu przyciągają uwagę użytkowników forów i grup dyskusyjnych, wywołując ożywione dyskusje na temat poczucia bezpieczeństwa. Jednak nawet w wątkach niezwiązanych z przekazami medialnymi kategorie bezpieczeństwa i stabilności zajmowały ważne miejsce w narracjach obu badanych grup migrantów. Biorąc zaś pod uwagę szerszy kontekst ich funkcjonowania w społeczeństwie przyjmującym, można uznać te kategorie za jedne z kluczowych dziedzin integracji (Ager i Strang 2004). W przypadku obu badanych grup integracja określana była jako konieczność poszanowania i przestrzegania norm obowiązujących w kraju docelowym oraz 
wiązana była z biegłą znajomością języka i nawiązywaniem kontaktów z przedstawicielami społeczeństwa przyjmującego.

Wśród najważniejszych kotwic obiektywnych zidentyfikowanych na podstawie przeprowadzonej analizy należy wymienić przejrzyste działanie instytucji oraz przewidywalność warunków instytucjonalnych, a także posiadanie stałego zatrudnienia, dzięki którym migranci osiągają poczucie stabilizacji w nowym kraju. Bardziej złożony charakter mają kotwice o mieszanym charakterze tkwiące w relacjach społecznych, bowiem migranci zakotwiczają się mentalnie w „wyobrażonych wspólnotach”, konstruując złożone klasowo-etniczne formy tożsamości, które stanowią ich punkty odniesienia w nowych warunkach społeczno-kulturowych.

Migranci z Polski w Wielkiej Brytanii rekonstruują swoją tożsamość w warunkach olbrzymiego zróżnicowania etnicznego, narodowego i kulturowego, budując hierarchie nie tylko w obrębie własnej grupy etnicznej, lecz także wśród licznych mniejszości etnicznych i grup emigrantów w Wielkiej Brytanii. W tym celu wykorzystują rozmaite linie podziału, podkreślając różnice klasowe i edukacyjne w obrębie własnej grupy etnicznej. Natomiast migranci z Ukrainy znajdują się w niemal całkowicie odwrotnej sytuacji - to oni są najliczniej reprezentowanymi, rozpoznawalnymi „obcymi” w homogenicznym społeczeństwie polskim. Rekonstruując tożsamość, odnoszą się zatem przede wszystkim do Polaków. Ich istotnym punktem odniesienia pozostają także wartości demokratyczne utożsamiane z Unią Europejską, obejmujące prawa i wolności obywatelskie, uczciwość, przejrzystość, praworządność, stawiane w opozycji do kondycji Ukrainy.

\section{Bibliografia}

Ager A., Strang A. (2004), Indicators of Integration. A Home Office Development and Practice Report, London: Home Office.

Babbie E. (2006), Badania społeczne w praktyce, przeł. W. Betkiewicz [et al.], Warszawa: Wydawnictwo Naukowe PWN.

Bargh J. A., McKenna K. Y. A., Fitzsimons G. M. (2002), Can you see the real me? Activation and expression of the "true self” on the Internet, „Journal of Social Issues”, Vol. 58, Issue 1, s. 33-48.

Batorski D. (2005), Internet a nierówności społeczne, „Studia Socjologiczne”, nr 2, s. 107-131.

Batorski D. (2015), Technologie i media w domach i w życiu Polaków. Diagnoza społeczna 2015. Warunki i jakość życia Polaków - Raport, „Contemporary Economics”, Vol. 9, Issue 4, s. 373-395.

Batorski D., Olcoń-Kubicka M. (2006), Prowadzenie badań przez Internet — podstawowe zagadnienia metodologiczne, „Studia Socjologiczne”, nr 3, s. 99-132.

Ben-Ze'ev A. (2003), Privacy, emotional closeness, and openness in cyberspace, „Computers in Human Behavior", Vol. 19, Issue 4, s. 451-467.

Bokszański Z. (2008), Tożsamości zbiorowe, Warszawa: Wydawnictwo Naukowe PWN.

Bottero W. (2004), Class Identities and the Identity of Class, „Sociology”, Vol. 38, Issue 5, s. 985-1003. 
Boyd D. M., Ellison N. B. (2008), Social Network Sites: Definition, History, and Scholarship, „Journal of Computer-Mediated Communication”, Vol. 13, Issue 1, s. 210-230.

Breton R. (1964), Institutional Completeness of Ethnic Communities and the Personal Relations of Immigrants, „American Journal of Sociology”, Vol. 70, Issue 2, s. 193-205.

British Sociological Association (2002), Statement of ethical practice for the British Sociological Association, https://www.britsoc.co.uk/media/23902/statementofethicalpractice.pdf [data dostępu: 21.02.2016].

Brownlow C., O’Dell L. (2002), Ethical Issues for Qualitative Research in On-line Communities, „Disability \& Society”, Vol. 17, Issue 6, s. 685-694.

Castells M. (2008), Siła tożsamości, przeł. S. Szymański, Warszawa: Wydawnictwo Naukowe PWN.

Cichocki P., Jędrkiewicz T., Zydel R. (2012), Etnografia wirtualna, w: Jemielniak D. (red.), Badania jakościowe. Metody i narzędzia, tom 2, Warszawa: Wydawnictwo Naukowe PWN, s. 203-220.

Dekker R., Engbersen G. (2014), How social media transform migrant networks and facilitate migration, „Global Networks”, Vol. 14, Issue 4, s. 401-418.

Dekker R., Engbersen G., Faber M. (2015), The Use of Online Media in Migration Networks, „Population, Space and Place”, Vol. 22, Issue 6, s. 539-551.

Denzin N. K. (1999), Cybertalk and the Method of Instances, w: Jones S. (red.), Doing Internet Research. Critical Issues and Methods for Examining the Net, London: SAGE Publications Ltd, s. 107-125.

DiMaggio P., Hargittai E., Celeste C., Shafer S. (2004), Digital Inequality: From Unequal Acess to Differential Use, w: Neckerman K. M. (red.), Social Inequality. New York: Russell Sage, s. $549-566$.

DiMaggio P., Hargittai E., Neuman W. R., Robinson J. P. (2001), Social Implications of the Internet, „Annual Review of Sociology”, Vol. 27, Issue 1, s. 307-336.

Domański H. (2007), Struktura społeczna, Warszawa: Wydawnictwo Naukowe Scholar.

Dutton W. H., Blank G., Groselj D. (2013), Cultures of the Internet: The Internet in Britain, Oxford, http://oxis.oii.ox.ac.uk/ [data dostępu: 09.01.2016].

Ess C. (2002), Ethical Decision-Making and Internet Research. Recommendations from the AoIR Ethics Working Committee, http://aoir.org/reports/ethics.pdf [data dostępu: 27.01.2016].

Eysenbach G., Till J. E. (2001), Ethical issues in qualitative research on internet communities, „British Medical Journal”, nr 323, s. 1103-1105.

De Fina A. (2013), Top-Down and Bottom-Up Strategies of Identity Construction in Ethnic Media, „Applied Linguistics”, Vol. 34, Issue 5, s. 554-573.

Galasinska A. (2010), Leavers and stayers discuss returning home: Internet discourses on migration in the context of the post-communist transformation, „Social Identities”, Vol. 16, Issue 3, s. 309-324.

Garapich M. P. (2008), The Migration Industry and Civil Society: Polish Immigrants in the United Kingdom Before and After EU Enlargement, „Journal of Ethnic and Migration Studies”, Vol. 34, Issue 5, s. 735-752.

Garapich M. P. (2010), Chłopi i żołnierze, budowlańcy i pijacy - dominujący dyskurs migracyjny, jego kontestacje oraz konsekwencje dla konstruowania polskiej grupy etnicznej w wielokulturowym Londynie, w: Grzymała-Moszczyńska H., Kwiatkowska A., Roszak J. (red.), Drogi i Rozdroża Migracje Polaków w Unii Europejskiej po 1 Maja 2004 Roku. Analiza Psychologiczno-Socjologiczna, Kraków: Zakład Wydawniczy Nomos, s. 35-54. 
Gergen K. J. (2009), Nasycone Ja. Dylematy tożsamości w życiu wspótczesnym, przeł. M. Marody, Warszawa: Wydawnictwo Naukowe PWN.

Grzymała-Kazłowska A. (2013), Zarys Koncepcji Społecznego Zakotwiczenia. Inne Spojrzenie Na Tożsamość, Adaptację i Integrację Imigrantów, „Kultura i Spoleczenstwo”, Vol. 57, Issue 3, s. 45-60.

Grzymała-Kazłowska A. (2015), Social Anchoring: Immigrant Identity, Security and Integration Reconnected? „Sociology”, doi:10.1177/0038038515594091.

Hargittai E. (2008), Whose space? Differences among users and non-users of social network sites, „Journal of Computer-Mediated Communication”, Vol. 13, Issue 1, s. 276-297.

Hargittai E., Hsieh Y. P. (2013), Digital Inequality, w: Dutton W. H. (red.), Oxford Handbook of Internet Studies, Oxford University Press, s. 129-150.

Kaplan A. M., Haenlein M. (2010), Users of the world, unite! The challenges and opportunities of Social Media, „Business Horizons”, Vol. 53, Issue 1, s. 59-68.

Krejtz K., Krejtz I. (2006), Ja w sieci - sieć we mnie. Zależności pomiędzy doświadczeniami w internecie a reprezentacją obrazu siebie, w: Batorski D., Marody M., Nowak A. (red.), Społeczna przestrzeń internetu, Warszawa: Wydawnictwo Szkoły Wyższej Psychologii Społecznej „Academica”, s. 91-112.

Kulyk V. (2006), Constructing common sense: Language and ethnicity in Ukrainian public discourse, „Ethnic and Racial Studies”, Vol. 29, Issue 2, s. 281-314.

Lange P. G. (2007), Publicly Private and Privately Public: Social Networking on YouTube, „Journal of Computer-Mediated Communication”, Vol. 13, Issue 1, s. 361-380.

Leonowicz-Bukała I. (2015), Polskie media w Wielkiej Brytanii na początku XXI wieku, Warszawa-Rzeszów: WSZiI-Aspra-JR.

Markham A., Buchanan E. (2012), Ethical Decision-Making and Internet Research. Recommendations from the AoIR Ethics Working Committee (Version 2.0), http://www.aoir.org/documents/ethics-guide, [data dostępu: 27.01.2016].

Matsaganis M. D., Katz V. S., Ball-Rokeach S. J. (2011), What Are Ethnic Media?, w: Matsaganis M. D., Katz V. S., Ball-Rokeach S. J. (red.), Understanding Ethnic Media Producers, Consumers, and Societies, Los Angeles: SAGE Publications, Inc., s. 3-24.

Mazurek P. (2006a), Anatomia internetowej anonimowości, w: Batorski D., Marody M., Nowak A. (red.), Społeczna przestrzeń internetu, Warszawa: Wydawnictwo Szkoły Wyższej Psychologii Społecznej „Academica”, s. 80-90.

Mazurek P. (2006b), Nowe media i tożsamość, w: Batorski D., Marody M., Nowak A. (red.), Społeczna przestrzeń internetu, Warszawa: Wydawnictwo Szkoły Wyższej Psychologii Społecznej „Academica”, s. 113-132.

Mitra A. (2001), Marginal voices in cyberspace, „New media \& society”, Vol. 3, Issue 1, s. 29-48.

Norris P. (2001), Digital Divide: Civic Engagement, Information Poverty, and the Internet Worldwide, Cambridge: Cambridge University Press.

Norris P. (2002), The Bridging and Bonding Role of Online Communities, „The Harvard International Journal of Press/Politics", Vol. 7, Issue 3, s. 3-13.

Olcoń-Kubicka M. (2006a), Blogi jako przejaw współczesnego trybalizmu, w: Batorski D., Marody M., Nowak A. (red.), Społeczna przestrzeń internetu, Warszawa: Wydawnictwo Szkoły Wyższej Psychologii Społecznej „Academica”, s. 147-161.

Olcoń-Kubicka M. (2006b), Uspołecznienie macierzyństwa przez dyskurs w przestrzeni internetowej, w: Batorski D., Marody M., Nowak A. (red.), Społeczna przestrzeń internetu, Warszawa: Wydawnictwo Szkoły Wyższej Psychologii Społecznej „Academica”, s. 267-281. 
Olcoń-Kubicka M. (2009), Indywidualizacja a nowe formy wspólnotowości, Warszawa: Wydawnictwo Naukowe Scholar.

Polskie Towarzystwo Socjologiczne (2012), Kodeks Etyki Socjologa, http://pts.org.pl/wp-content/ uploads/2016/04/kodeks.pdf [data dostępu: 21.02.2016].

Schwartz S. J., Montgomery M. J., Briones E. (2006), The role of identity in acculturation among immigrant people: Theoretical propositions, empirical questions, and applied recommendations, „Human Development”, Vol. 49, Issue 1, s. 1-30.

Sharf B. F. (1997), Communicating breast cancer on-line: support and empowerment on the Internet, „Women Health”, Vol. 26, Issue 1, s. 65-84.

Turkle S. (1995), Life on the Screen. Identity in the Age of the Internet, New York: Simon and Schuster.

Warschauer M. (2004), Technology and Social Inclusion: Rethinking the Digital Divide, Cambridge, Massachusetts: MIT Press.

White A., Ryan L. (2008), Polish "temporary" migration: The formation and significance of social networks, „Europe-Asia Studies”, Vol. 60, Issue 9, s. 1467-1502. 